\title{
Resource Allocation, Level of International Diversification and Firm Performance
}

\author{
Aziz Bakay (Corresponding author) \\ A.R. Sanchez, Jr. School of Business, Texas A\&M International University \\ 5201 University Boulevard, WHTC 211, Laredo TX 78041, USA \\ Tel: 1-956-326-2552 E-mail: azizbakay@dusty.tamiu.edu \\ Ahmed Elkassabgi \\ A.R. Sanchez, Jr. School of Business, Texas A\&M International University \\ 5201 University Boulevard, WHTC 211, Laredo TX 78041, USA \\ Tel: 1-956-326-2552 E-mail: ahmed@dusty.tamiu.edu \\ Murad Moqbel \\ A.R. Sanchez, Jr. School of Business, Texas A\&M International University \\ 5201 University Boulevard, WHTC 211, Laredo TX 78041, USA \\ Tel: 1-956-326-2552_E-mail: muradmoqbel@dusty.tamiu.edu
}

Received: January 20, $2011 \quad$ Accepted: July 22, $2011 \quad$ Published: December 1, 2011

doi:10.5539/ijbm.v6n12p87ＵRL: http://dx.doi.org/10.5539/ijbm.v6n12p87

\begin{abstract}
This paper investigates the threads between international diversification and firm performance, resource allocation to R\&D and capital expenditure. The context of this study is a resource-based view and transaction costs theory. Firms that are going international, benefit from the resources available to them outside their home country as well as from the utilization of their core competencies in other countries. Regression models without interactive terms indicate that resource allocation significantly impacts firm performance. Capital expenditure is positively associated with return on assets, while research and development expenditure undermines the firm's performance. Analyses suggest that there is no thorough relation between international diversification and returns, regardless of using asset or sales diversification variables. The estimates of diversification variable are negative and insignificant in most models.
\end{abstract}

Keywords: International diversification, Return on assets, R\&D expenditure, Capital expenditure

\section{Introduction}

Generating income, increasing stakeholders' wealth, or providing both material and immaterial needs of society, are various business methods firms use to grow strong. The monetary returns as one of the ultimate goals of the firm, and acting on the interests of shareholders have been targets for managers. The paths towards such goals are achieved by means of strategic decision making, employing strategies that fit to the firm's internal and external environment. These may include, focusing on manufacturing quality, differentiating in service providing, or restructuring the firm's cost structure. Nevertheless, the determinants of firm performance and firm value are numerous and intertwined in many aspects. The impacts of R\&D expenditure, capital expenditure, and industry profitability on firm performance are discussed in earlier studies (Stimpert \& Duhaime, 1997; Hitt, Hoskisson \& Kim, 1997; Wernerfelt \& Montgomery, 1986).

This paper investigates the threads between resource allocation to $\mathrm{R} \& \mathrm{D}$, capital expenditure, international diversification, and their individual and interactive impacts on firm performance. The context of this study is a resource-based view and transaction costs theory. Firms that are going international benefit from the resources available to them outside their home country as well as from the implementation of their core competencies in 
other countries. The compartmentalization of such benefits into the constructs of variables is discussed.

\subsection{Resource-based View and Transaction Cost Theory}

What is under control of the firm, what can be utilized in the production of goods or services by the firm management, and what can enable the firm to "conceive of and implement strategies" are the within the frontiers of the firm resources (Barney, 1991: 101). Barney (1991) defined the resources as scattered heterogeneously among firms in a market and whose supposed nature is of imperfect imitability. In this regard, the complexity and ambiguity of employment of resources by a firm create barriers for other competitors to imitate (Reed and DeFillippi, 1990). This perspective indicates the fact that there is a unique and optimum set of resources for an entity to achieve efficient and effective outcomes. Another study by Markides and Williamson (1994), found that not only having strategic assets help firms perform better but also building up strategic assets faster in a competitive environment would lead to superior performance. Assuming the necessary importance of tangible assets to the firm, the intangible resources, such as knowledge, are also imperative essences of the firms when integrated and utilized within the firm strategy. Similarly, such resources create competitive advantage in the global context when the transfer of knowledge to other countries is maintained in an efficient way (Kogut \& Zander, 1993). An earlier study found that industry attractiveness is not the focal point for a diversifier unless the diversifier is efficient (Wernerfelt \& Montgomery, 1986).

From a transaction cost point of view, engaging into multiple markets in different contexts of countries which are new to the firm would require better communication and network skills to handle the unfamiliarity of the new markets. Thus, the success of an international firm is tied into the efficiency of benefiting the opportunities and implementing the know-how in a global market. Besides, the international diversification has implementations and positive repercussions on the extent of innovation experience that the firm is undertaking (Hitt et al., 1997). Therefore, increasing the shareholder wealth through international diversification is evidenced in a study encompassing West German corporations (Buhner, 1987).

The intentions of diversifying internationally are different than that of diversifying domestically. The international diversification strategy is thereupon employed when the firm is basically 'pulled' by the external factors that could allow the exploitation of the prospective global markets, rather than risk reduction purposes (Buhner, 1987). Domestic firms may move into the international arena whenever the management sees the domestic market becoming saturated. On the contrary, from a more financial perspective, the risk reduction is proposed to be a desirable and feasible goal of international diversification (Rugmen, 1976).

\subsection{Overview of Conceptual Framework}

This study utilizes the transaction costs theory and resource-based view of the firm. The extant literature regarding the diversification strategies of firms is excessive (Ramanujam and Varadarajan, 1989). The highly-regarded diversification taxonomy was brought into literature by Rumelt (1974) that has been a ground for many academic works (Bettis, 1981; Chatterjee \& Wenerfelt, 1991). However, there has not been substantial work on the international diversification and its determinants.

Concerning the scope of this paper, allocation of resources as R\&D and capital expenditures are discussed in terms of their impact on the business performance. The firms' innovative frontier is constraint by some limits such as human resources, expenditures of research and development divisions, the fit between R\&D divisions and the business units. Expectation of both low cost and quality products in the global market motivates and drives firms into a focus of research and development even more (Hitt et al., 1997). Some certain bundles of resources in a firm environment create advantage for business entity if the process of strategy formulation can estimate the price of such resources and deploy an optimum specialized set of resources (Lippman \& Rumelt, 2003). The hypotheses stated for resource allocation are basically the followings: Higher R\&D and capital expenditure lead to better performance output. The international diversification for those firms capable of going international, leads to better performance of the firm. Figure 1 is the proposed framework to be analyzed in this particular study.

The followings are the hypothesis with regards to our conceptual model.

$\mathrm{H}_{1}$ : The $\mathrm{R} \& \mathrm{D}$ expenditure is positively associated with firm performance.

$\mathrm{H}_{2}$ : The capital expenditure is positively associated with firm performance.

$\mathrm{H}_{3}$ : International diversification is positively associated with the firm performance.

$\mathrm{H}_{4}$ : International diversification has positive correlation with $\mathrm{R} \& \mathrm{D}$ and capital expenditure.

$\mathrm{H}_{5}$ : Interactive terms of $\mathrm{R} \& \mathrm{D}$, capital expenditure and international diversification (dual impacts) have positive impact on firm performance. 


\section{Methodology}

\subsection{Variables}

Performance of the firms is measured by the return on assets (ROA). International diversification is the proportion of foreign sales to the total sales of the firm. Total R\&D expenditure will be divided by the total assets to operationalize in the framework. R\&D intensity of a firm is measured to see to what extent the firm has a focus on improving the innovation as a competitive strategy implementation. By the same token, we used a ratio of capital expenditure to total assets, so that the size of the company would be factored out and bigger firms would not imply higher capital expenditure.

International diversification is operationalized as the ratio of foreign sales to total sales. The data is again pulled from COMPUSTAT segment data base. This measure includes the sales from identified geographic segments minus its allocated share of operating costs and expenses (i.e. COGS, selling, general and administrative expenses, and depreciation, depletion and amortization). The foreign sales and foreign assets are given for each geographical region in which the firm is operating. Therefore, for some of the firms there are several foreign sales and assets observations due to multiple geographic segments associated with the firms operations. The firm country of domicile is not restricted to the United States. Thus, the foreign geographic segments include continental segments such as the United States, Europe, Asia as well as some individual countries. Not all firms have the same span of geographical operations. In the COMPUSTAT raw data, foreign segment observations for sales and assets are subtotaled giving the total amount of sales and assets for all foreign segments.

In order to attain a robust diversification variable, beside sales information, foreign assets are also pulled and divided by total assets for firms in the sample. Regression results regarding the asset diversification variable is also provided in results section. In addition, only observations that have diversification ratio higher than $5 \%$ are included in our sample.

\subsection{Sample}

The sample consisted of 102 manufacturing firms for the period of 1976-2009. The initial sample size is 1730 . Data is pulled from both COMPUSTAT annual and COMPUSTAT segment database. The segment database provides information regarding the geographic segments of the operations of each firm. The descriptive statistics and correlation matrix are given in Table 1 and 2.

\subsection{Diagnostics}

The data diagnostics generated a number of outliers that could distract the regression results as well as the normality assumptions. First, the studentized residuals are calculated and observations whose absolute values of residuals are more than 2.5 are excluded from the regressions. The highest (9.65) and lowest (-13.54) residuals are observations of AMCOL International Corp. and Freescale Semiconductor INC, respectively. Eliminating the observations with high residuals decreased the sample size from the initial 1730 to 1685 .

Normality of residuals is tested by a command (iqr) in STATA. Inter-quartile range (iqr) assumes the symmetry of the distribution of residuals. The command reveals if there are severe outliers that are either three inter-quartile-ranges below the first quartile or three inter-quartile-ranges above the third quartile. The residuals do not happen to have normal distribution and there is one severe outlier that allows the rejection of normality at $5 \%$ level. Another diagnostics test, Shapiro-Wilk W test, appears to be significant and therefore rejecting the normality of residuals.

We utilized Breusch-Pagan test and Cameron \& Trivedi's decomposition of IM-test for variance of fitted values of our dependent variable (ROA). The former test fails to reject (prob $>$ chi $2=0.28$ ) homoscedasticity. However, the latter test confirms the existence of heteroscedasticity $(\mathrm{p}<0.001)$.

\subsection{Models}

We have employed multiple regression, robust regression, random and fixed effects models. First model includes only the primary variables of interest. Second model includes the interaction of primary variables as well as their main effects. Third model excludes the outliers. Fourth model is a robust regression excluding the outliers. Fifth model is OLS regression analysis including the industry dummy variables, excluding the outliers. Therefore, the model captures the different industry characteristics. Sixth model is a robust regression of fifth model.

The dependent variable is the performance of the firm and the primary independent variables are R\&D expenditure, capital expenditure, and international diversification. Panel data is obtained from COMPUSTAT having multiple year observations of variables for every firm. However, not all firm data has the same time span resulting in unbalanced panel data.

Base Model: 


$$
\mathrm{ROA}_{i}=\alpha+\beta_{1} * \mathrm{RD}_{i}+\beta_{2} * \mathrm{CAP}_{i}+\beta_{3} * \mathrm{DV}+e_{i}
$$

Model with industry dummies:

$$
\mathrm{ROA}_{i}=\alpha+\beta_{1} * \mathrm{RD}_{i}+\beta_{2} * \mathrm{CAP}_{i}+\beta_{3} * \mathrm{DV}+\mathrm{V}_{\text {ind }}+e_{i}
$$

Model with interaction terms:

$$
\begin{aligned}
\mathrm{ROA}_{i}=\alpha+ & \beta_{1} * \mathrm{RD}_{i}+\beta_{2} * \mathrm{CAP}_{i}+\beta_{3} * \mathrm{DV}_{\boldsymbol{i}} \\
& +\beta_{4} * \mathrm{RD}_{i} * \mathrm{CAP}_{i} \quad+\beta_{5} * \mathrm{RD}_{i} * \mathrm{DV}_{i}+\beta_{6} * \mathrm{CAP}_{i} * \mathrm{DV}_{\boldsymbol{i}}+e_{i}
\end{aligned}
$$

Where;

$\mathrm{ROA}_{i:}$ Return on assets of a firm at time $i$.

$\mathrm{RD}_{i}: \mathrm{R} \& \mathrm{D}$ expenditure / Total Sales at time $i$.

CAP $_{i}$ : Capital expenditure / Total Sales at time $i$.

$\mathrm{DV}_{i}$ : Foreign sales / Total sales at time $i$.

$\mathrm{V}_{\text {ind: }}$ Industry dummy variables.

$\mathrm{e}_{i}$ : Error term.

Models have used these two diversification measures separately, reporting the generated outcomes for each measure and for a composite of the two measures. The composite measure is simply the average of two proportions: foreign sales to total sales and foreign assets to total sales.

\section{Results}

OLS and robust regression results are given in Table 3 and Fixed and Random effects models are given in Table 4. In model 1 , every variable is significant under $1 \%$ level therefore, the overall significance of the model (F-stat) imply a good fit. Diversification $(-0.032)$ and $R \& D$ expenditure $(-0.270)$ have negative signs therefore as all other factors kept constant, increasing the sales diversification ratio or increasing the allotted resources on Research and Development department, the return on assets is expected to decrease. On the other hand, higher capital expenditure is related with higher return on assets. The R-squared is $5 \%$ which is a relatively low number. The R-squared around $20 \%$ would be satisfactory in a typical social science study, thus our models have a limitation in explaining the overall variance of the dependent variable.

In models (2) and (2a), the outliers are left out not resulting in a substantial change in the generated outputs. Sales diversification is negative and significant, $R \& D$ expenditure is again negative but not significant and capital expenditure is at similar levels. Asset diversification variable (2a) is not significant but it is a negative and very small number.

As the interaction terms are included the overall explanation of variance of dependent variable does not virtually increase. On the contrary, the significance of variables disappear and the only remaining significant explanatory factor remains is capital expenditure which is significant in all regressions. Capital expenditure ranges from 0.29 to 0.37 across six models.

Robust regression generates a significant negative diversification estimate $(-0.021)$ and significant capital expenditure (0.29). The last regression in Table 3 includes the industry dummy variables that substantially increase the R-squared to 0.30, having an F-stat of 14.14. Regression generates a negative Research and Development expenditure estimate and positive Capital expenditure estimates both of which are at similar levels as compared with the previous estimates. Therefore, taking into the industry characteristics account, the dummy variables strengthen the overall explanation of the variation in returns across firms. Different industry characteristics covary with return levels, as well as different firm strategies do in terms of resource allocation.

Fixed and random effects are utilized in addition to several OLS and robust regression analysis. In fixed effects model, diversification is estimated to be negative. However, it is statistically insignificant. Research and development expenditure significantly undermines returns. Capital allocation variables are significant under $1 \%$ level. Overall model's significance (F-stat: 33.61) indicates a good fit of the set of the variables. However, the $\mathrm{R}$-squared is as low as $6 \%$.

In the random effects model, diversification is not statistically significant whereas R\&D $(-0.2366)$ and capital expenditure (0.3675) are significant under $1 \%$ level. The R-squared within is just below $6 \%$ and the R-squared between and overall is $4 \%$.

Fixed effects and random effects are used in our panel data regression analyses and Hausman test $(p>0.1373)$ revealed that using random effects allows the analysis fit to the data better. Nevertheless, the outcomes of both models are largely similar with the exception of lower coefficient of R\&D expenditure in the random effects 
model. Both of random and fixed effects models results are provided.

\section{Limitations}

Various countries have different market structure and prospects where the allocation of resources can vary. Therefore, country of origin and country characteristics may change the strategies of firms based on the unique political/legal and economic environments. Thus, firms originating in different countries may have varying priorities. In our study, we have not accounted for variations of country of origin of firms. Further studies can investigate similar research questions taking country characteristics into consideration. The resource allocation in firms that are in the same industry could be much more similar than those firms of other industries. Also, geographical segmentation of firms could be another factor influencing the international diversification. Firms' countries of domiciles that are in close proximity to other international markets may be considered as a natural advantage granted to the firms. Therefore, among other factors, these are issues to be discussed and incorporated in future studies regarding resource allocation and firm performance. The analysis is limited to three variables, which are diversification, $R \& D$ and capital expenditure, and in order to extend the understanding and to extract more insights, firm level accounting data can be pulled. As such, various asset units (investment assets, intangible assets), debt structure are among those that could be operationalized from the income statements and/or balance sheets of the firms.

\section{Discussion and Conclusion}

This paper addresses the question of how resource allocation and international diversification impact firm performance. The hypotheses are tested through regression analysis employing various models. First model employed base variables of capital and R\&D expenditures, international diversification, and all of them are significantly impacting the firm returns. Resource allocation has varying consequences depending on what kind of expenditure is made. This particular study reveals that research and development expenditures on average undermine the firm performance. Contrary to some of the literature (i.e. Hitt et al., 1997), we don't find support for the argument of the positive link between R\&D and firm performance. How and why a firm undertakes research and development should be made clear before the actual expenditure takes place. Its consequences, repercussions and responsibilities that management would assume should be reckoned and scaled very carefully. The capital expenditure extends the firm performance at similar levels in almost all models. Confirming with the prior research (Lippman \& Rumelt, 2003), the resource allocation decision pertaining to the expansion of the firm capital, on average, leads to prolific firm operations. The hypothesis 2 is supported.

Excluding the industry dummy variables, the models have weak explanation of the variation in firm returns. In addition, the diversification variable is estimated to be negative in all models, but significant in three out of eight models regardless of its being asset diversification or sales diversification. Our analysis produced results that are not conclusive regarding the impact of international diversification. We conclude with caution that the relationship between international diversification and firm performance is more sophisticated than being a linear association. However, we cannot support our hypothesis 3 that proposed a positive association between these constructs. With regards to hypothesis 4 , sales diversification is positively and significantly correlated with R\&D expenditure (0.09) whereas asset diversification is negatively and significantly correlated with R\&D expenditure $(-0.07)$. Both diversification (sales and asset) variables have very low correlation coefficients with capital expenditure. Therefore, the relationships between these constructs are not conclusive. Thus, we cannot support hypothesis 4 . In addition, the interactive terms are not estimated significantly, not supporting hypothesis 5.

The determinants of international diversification are still an issue to be studied further and more comprehensive academic perspectives should be developed for a better understanding. In addition, casting different approaches from various disciplines would strengthen the insights derived from the data. To sum up, the resource allocation has been among the critical strategic decisions of firms. The set of optimum resources allocated are primary issues for management team to bear in mind. Going international has been an issue dependent upon capability, market prospects, opportunities that are attracting the firm to engage in global markets.

\section{References}

Barney, J. (1991). Firm resources and sustained competitive advantage. Journal of Management, 17(1), 99-120. http://dx.doi.org/10.1177/014920639101700108

Bettis, R. (1981). Performance differences in related and unrelated diversification. Strategic Management Journal, 2(4), 379-393. http://dx.doi.org/10.1002/smj.4250020406

Buhner, R. (1987). Assessing international diversification of West German corporations. Strategic Management Journal, 8(1), 25-37. http://dx.doi.org/10.1002/smj.4250080104

Chatterjee, S., \& Wenerfelt B. (1991). The link between resources and type of diversification: Theory and evidence. Strategic Management Journal, 12(1), 33-48. http://dx.doi.org/10.1002/smj.4250120104 
Hitt, M. A., Hoskisson, R. E., \& Kim, H. (1997). International diversification: Effects on innovation and firm performance in product-diversified firms. Academy of Management Journal, 40(4), 767-798. http://dx.doi.org/10.2307/256948

Kogut, B., \& Zander, U. (1993). Knowledge of the firm and the evolutionary theory of the multinational corporation. Journal of International Business Studies, 24(4), 625-645. http://dx.doi.org/10.1057/palgrave.jibs.8490248

Lippman, A. S., \& Rumelt, P., R. (2003). A bargaining perspective on resource advantage. Strategic Management Journal, 24(11), 1069-1086. http://dx.doi.org/10.1002/smj.345

Markides, C., \& Williamson, P. (1994). Related diversification, core competences and corporate performance. Strategic Management Journal, 15(special issue), 149-165.

Ramanujam, V., \& Varadarajan, P. (1989). Research on corporate diversification: A synthesis. Strategic Management Journal, 10(6), 523-551. http://dx.doi.org/10.1002/smj.4250100603

Reed, R., \& DeFillippi, R. J. (1990). Causal ambiguity, barriers to imitation, and sustainable competitive advantage. Academy of Management Review, 15(1), 88-102. http://dx.doi.org/10.5465/AMR.1990.4308277

Rugmen, A. (1976). Risk reduction by international diversification. Journal of International Business Studies, 7(2), 75-80. http://dx.doi.org/10.1057/palgrave.jibs.8490702

Rumelt, R. (1974). Strategy, structure and economic performance. Boston: Harvard University Press.

Stimpert, J. L., \& Duhaime, I. M. (1997). Seeing the big picture: The influence of industry, diversification, and business strategy on performance. Academy of Management Journal, 40(3), 560-583. http://dx.doi.org/10.2307/257053

Wernerfelt, B., \& Montgomery, C. A. (1986). What is an attractive industry? Management Science, 32(10), 1223-1230. http://dx.doi.org/10.1287/mnsc.32.10.1223

Table 1. Descriptive Statistics

\begin{tabular}{|r|c|c|c|c|c|}
\hline & Obs. & Mean & Std. Dev. & Min & Max \\
\hline $\begin{array}{r}\text { Diversification } \\
\text { (Foreign Sales / Total Sales) }\end{array}$ & 1664 & 0.453 & 0.240 & 0.051 & 1.000 \\
Diversification & 1415 & 0.408 & 0.215 & 0.050 & 0.992 \\
(Foreign Assets / Total Assets) & 1664 & 0.060 & 0.063 & -0.204 & 0.300 \\
Return on Assets & 1664 & 0.040 & 0.043 & 0.000 & 0.423 \\
R\&D Expenditure & 1664 & 0.058 & 0.379 & 0.004 & 0.390 \\
Capital Expenditure & 164
\end{tabular}

Table 2. Correlation Matrix

\begin{tabular}{|r|c|c|c|c|c|}
\hline & $\begin{array}{c}\text { Diversification } \\
\text { (Foreign Sales } \\
\text { / Total Sales) }\end{array}$ & $\begin{array}{c}\text { Diversification } \\
\text { (Foreign Assets / } \\
\text { Total Assets) }\end{array}$ & $\begin{array}{c}\text { Return on } \\
\text { Assets }\end{array}$ & $\begin{array}{c}\text { R\&D } \\
\text { Expenditure }\end{array}$ & $\begin{array}{c}\text { Capital } \\
\text { Expenditure }\end{array}$ \\
\hline $\begin{array}{r}\text { Diversification } \\
\text { (Foreign Sales / Total Sales) }\end{array}$ & 1 & & & & \\
$\begin{array}{r}\text { Diversification } \\
\text { (Foreign Assets / Total Assets) }\end{array}$ & $0.80 *$ & 1 & & & \\
Return on Assets & $-0.07 *$ & -0.02 & 1 & & \\
R\&D Expenditure & $0.09 *$ & $-0.07 *$ & -0.04 & 1 & \\
Capital Expenditure & -0.03 & -0.003 & $0.21 *$ & $-0.07 *$ & 1 \\
\hline
\end{tabular}

Significance level (5\%). Number of observations is 1415 . 
Table 3. OLS and Robust Regression Results

\begin{tabular}{|c|c|c|c|c|c|c|}
\hline Model \# & (1) & (2) & (2a) & (3) & (4) & (5) \\
\hline Variables & $\begin{array}{l}\text { Base } \\
\text { Model }\end{array}$ & $\begin{array}{c}\text { w/o outliers } \\
\text { (Sales diversif.) }\end{array}$ & $\begin{array}{c}\text { w/o outliers } \\
\text { (Asset diversif.) }\end{array}$ & $\begin{array}{c}(2)+ \\
\text { Interactions } \\
\text { Model }\end{array}$ & $\begin{array}{l}(2)+\text { Robust } \\
\text { Regression }\end{array}$ & $\begin{array}{c}(2)+\mathrm{w} \\
\text { /industry dummies }\end{array}$ \\
\hline \multirow{2}{*}{ Diversification (a) } & $-0.032 * * *$ & $-0.018 * * *$ & -0.002 & -0.021 & $-0.021 * * *$ & -0.001 \\
\hline & $(0.0094)$ & $(0.0063)$ & $(0.0075)$ & $(0.0133)$ & $(0.0054)$ & $(0.0071)$ \\
\hline \multirow{2}{*}{ R \& D Expenditure (b) } & $-0.270 * * *$ & -0.0542 & $-0.069 *$ & -0.049 & 0.048 & $-0.380 * * *$ \\
\hline & $(0.0497)$ & $(0.0347)$ & $(0.0380)$ & $(0.0978)$ & $(0.0297)$ & $(0.0526)$ \\
\hline \multirow{2}{*}{ Capital Expenditure (c) } & $0.3645 * * *$ & $0.350 * * *$ & $0.339 * * *$ & $0.302 * * *$ & $0.290 * * *$ & $0.3727 * * *$ \\
\hline & $(0.0599)$ & $(0.0042)$ & $(0.0429)$ & $(0.0971)$ & 0.0342 & 0.0408 \\
\hline (a) * (b) & & & & $\begin{array}{l}-0.033 \\
(0.1475)\end{array}$ & & \\
\hline (a) * (c) & & & & $\begin{array}{l}0.791 \\
(0.1506)\end{array}$ & & \\
\hline (b) * (c) & & & & $\begin{array}{l}0.211 \\
(1.0152)\end{array}$ & & \\
\hline \multirow{2}{*}{ Constant } & $0.060 * * *$ & $0.0521 * * *$ & $0.0479 * * *$ & $0.0543 * * *$ & $0.054 * * *$ & $0.020 * *$ \\
\hline & $(0.0063)$ & $(0.0042)$ & $(0.0047)$ & $(0.0075)$ & $(0.0036)$ & $(0.0093)$ \\
\hline F-stat & 30.28 & 30.79 & 23.03 & 15.44 & \multirow[t]{3}{*}{30.00} & 14.14 \\
\hline R-squared & 0.05 & 0.05 & 0.05 & 0.05 & & 0.30 \\
\hline Adj. R-squared & 0.04 & 0.05 & 0.04 & 0.04 & & 0.28 \\
\hline Number of Obs. & 1730 & 1685 & 1436 & 1685 & 1685 & 1685 \\
\hline
\end{tabular}

Significance levels are $10 \%(*), 5 \%(* *), 1 \%(* * *)$.

Numbers in parentheses are standard errors. Industry dummy coefficients are not shown.

Dependent variable: ROA

Table 4. Fixed and Random Effects Results

\begin{tabular}{|r|l|l|}
\hline & $\begin{array}{l}\text { Fixed } \\
\text { Effects }\end{array}$ & $\begin{array}{c}\text { Random } \\
\text { Effects }\end{array}$ \\
\hline Diversification & -0.0126 & -0.0136 \\
R \& D Expenditure & $-0.3038 * * *$ & $-0.2366 * * *$ \\
Capital Expenditure & $0.3696 * * *$ & $0.3675 * * *$ \\
Constant & 0.059 & \\
\hline F-stat & 33.61 & \\
R-squared within & 0.06 & 0.059 \\
R-squared between & 0.038 & 0.045 \\
R-squared overall & 0.038 & 0.043 \\
\hline Number of groups & 102 & 102 \\
Number of Obs. & 1685 & 1685 \\
Wald & & 102.84 \\
\hline & \multicolumn{2}{|l}{}
\end{tabular}

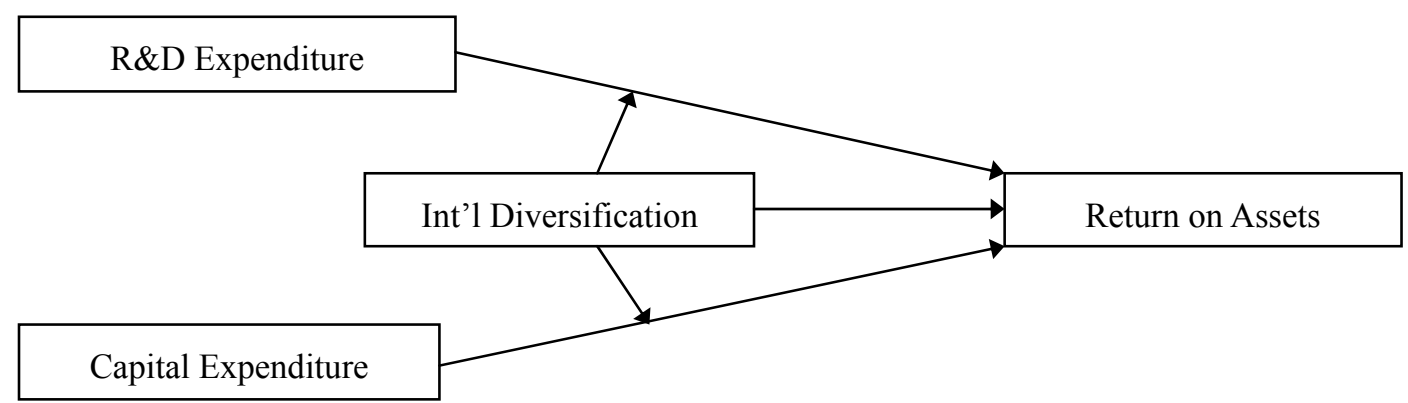

Figure 1. Conceptual Framework 